\title{
The taxonomy and anatomy of rauisuchian archosaurs from the Late Triassic of Germany and Poland
}

Stephen L. Brusatte, Richard J. Butler, Tomasz Sulej, and Grzegorz Niedźwiedzki

Acta Palaeontologica Polonica 54 (2), 2009: 221-230 doi:http://dx.doi.org/10.4202/app.2008.0065

The German Late Triassic archosaur Teratosaurus suevicus is a historically important taxon, being the first described rauisuchian. Unfortunately the holotype is a single element, a maxilla, which is poorly preserved and incomplete. We

redescribe this maxilla and identify a single potential autapomorphy. The fragmentary type specimen complicates attempts to refer additional material to this taxon, and other unassociated archosaur and rauisuchian specimens from the Mittlerer Stubensandstein of Germany cannot be referred to T. suevicus with any degree of confidence. The stratigraphically older $T$. silesiacus, from the upper Carnian of Poland, is represented by a much more complete and better preserved specimen. Comparison of the maxillae of $T$. suevicus and $T$. silesiacus reveals that the two are distinct taxa, contra recent suggestions, but also that they do not share any synapomorphies or a unique combination of characters relative to Postosuchus kirkpatricki and other rauisuchians. Thus, the Polish material must be transferred to a new genus, Polonosuchus gen. nov. Both Polonosuchus and Teratosaurus are very similar to Postosuchus kirkpatricki, and the three taxa are likely closely related.

Key words: Archosauria, Rauisuchia, taxonomy, Triassic, Germanic Basin.

Stephen L. Brusatte [sbrusatte@amnh.org], Department of Earth Sciences, University of Bristol, Wills Memorial Building, Queens Road, Bristol, BS8 1RJ, UK; present address: Division of Paleontology, American Museum of Natural History, Central Park West at 79th St., New York, NY, 10024, USA and Department of Earth and Environmental Sciences, Columbia University, New York, NY, USA; Richard J. Butler [R.Butler@nhm.ac.uk], Department of Palaeontology, The Natural History Museum, Cromwell Road, London, SW7 5BD, UK; present address: Bayerische Staatssammlung für Paläontologie und Geologie, Richard-Wagner-Straße 10, 80333 München, Germany; Tomasz Sulej [sulej@twarda.pan.pl ], Instytut Paleobiologii PAN, Twarda 51/55, PL-00-818, Warszawa, Poland; Grzegorz Niedźwiedzki [gniedzwiedzki@biol.uw.edu.pl], Instytut Zoologii Uniwersytetu Warszawskiego, Banacha 2, PL-02-079 Warszawa, Poland. 
This is an open-access article distributed under the terms of the Creative Commons

Attribution License (for details please see creativecommons.org), which permits unrestricted use, distribution, and reproduction in any medium, provided the original author and source are credited.

Forill text $(378.1 \mathrm{kB})$ 